DOI: $10.21802 / \mathrm{artm} .2020 .3 .15 .155$.

УДК 616.33-006.6

\title{
ФОРМУВАННЯ СТРАВОХІДНО-ТОНКОКИШКОВОГО АНАСТОМОЗУ ПІСЛЯ ЛАПАРОСКОПІЧНОЇ ТОТАЛЬНОЇ ТА ЛАПАРО-АСИСТОВАНОЇ ГАСТРОЕКТОМІЇ У ХВОРИХ НА РАК ШЛУНКУ
}

\author{
I.А. Сухін, Р.І. Верещако, О.О. Піскорський, О.М. Білиловець, Р.С. Гилевич
}

Національний медичний університет імені О.О. Богомольия, кафедра онкології, м. Київ, Україна, ORCID ID: 0000-0002-0177-9306, ORCID ID: 0000-0002-5706-6823,

ORCID ID: 0000-0002-2202-4201, ORCID ID: 0000-0002-4689-5490,

ORCID ID: 0000-0002-2046-6006,

e-mail:kklzt3@gmail.com

Резюме. Сьогодні рак шлунку стоїть на другому місті серед причин смерті від онкологічних захворювань. Існує два варіанти хірургічного лікування потенційно виліковних пацієнтів з неметастатичним раком шлунку, це лапароскопічна та відкрита гастроектомія. Відповідно є необхідність обговорення варіантів формування стравохідно-тонкокишкового анастомозу за методиками, які максимально спрощені, надійні, безпечні для пацієнта та економічно прийнятні. В статті досліджено методи формування різних типів стравохіднотонкокишкових анастомозів, зокрема при лапароскопічній тотальний та лапаро-асистований гастроектомії. В роботі аналізуються результати лікування всього 41 пацієнта.

Чоловіків було 29, жінок 12. Середній вік пацієнтів складав $57 \pm 9$ років, середній індекс маси тіла (IMT) 25,0 \pm 2,9. 3 метою прогнозування операційного ризику, фізичний стан пацієнтів оцінювали за шкалою, розробленою Американським Товариством Анестезіологів (ASA). Аналіз характеристики пухлини дозволив визначити стадію онкологічного захворювання як II у 17 пацієнтів та III у 24 пацієнтів. Вибір методу формування анастомозу залежить від досвіду хірурга, анатомічних особливостей пацієнта та економічної складової за кількістю розхідних матеріалів.

7 пацієнтам була виконана лапароскопічна тотальна гастроектомія з формуванням інтракорпорального анастомозу. Решті 34 пацієнтам виконувалась лапаро-асистована тотальна гастроектомія з формуванням циркулярного степлерного анастомозу двома способами:

1) введення зшивального апарату через місце майбутнього анастомозу за Брауном, кукса відвідної петлі тонкої кишки зашивалась відразу після пересічення тонкої кишки, за такою методикою були сформовані стравохідно-тонкокишкові анастомози у 23 пацієнтів;

2) введення зшивального апарату через куксу тонкої кишки з подальшим їі зашиванням після формування анастомозу, такий підхід використано у 11 випадках.

Ключові слова: гастректомія, стравохідно-тонкокишковий анастомоз, рак шлунку.

Вступ. Кожного року в світі діагностується близько мільйона нових випадків захворювання на рак шлунку та близько дев'ятисот тисяч смертей, що ставить це захворювання на четверте місце за поширеністю серед онкологічних захворювань та на друге серед причин смерті від раку [1]. На сьогодні хірургічне втручання залишаться найбільш ефективним методом лікування в резектабельних стадіях раку шлунку. 3 того часу, як у 1994 році вперше було повідомлено про виконання лапароскопічної гастректомії [4], кількість хворих, прооперованих таким способом, в світі невпинно зростає. Рандомізовані контрольовані та ретроспективні дослідження вказують на те, що лапароскопічна гастроектомія не поступається відкритій за онкологічними результатами [2]. Окрім того, лапароскопічні втручання мають значні переваги в швидкості відновлення фізичної активності пацієнтів та меншій кількості інтра- та післяопераційних ускладнень [3].

У цілому лапароскопічну гастроектомію (ЛГ) можна розділити на лапаро-асистовану гастроектомію (ЛАГ) та тотальну лапароскопічну гастроектомію
(ЛТГ) [5]. Під час виконання лапаро-асистованої методики мобілізація шлунку, абдомінальної частини стравоходу, лімфодисекція та відсічення шлунку від дванадцятипалої кишки виконується лапароскопічно, а відсічення шлунку від стравоходу та формування стравохідно-тонкокишкового анастомозу (СТА) виконується через мінілапаротомію в епігастральній ділянці. Складності при формуванні анастомозу при цій методиці можуть виникати при замалому розрізі, товстій черевній стінці та призводити до больового синдрому в післяопераційному періоді чи формування спайкового процесу в ділянці анастомозу. При повністю лапароскопічному варіанті формування СТА відбувається в черевній порожнині за наявності карбоперитоніуму. Більшість авторів схиляються до думки, що формування інтракорпорального анастомозу більш щадне та безпечне, супроводжується меншим спайковим процесом, такі анастомози менше схильні до розвитку стриктур [6,7].

Обгрунтування дослідження. Незважаючи на певні переваги, методика інтракорпорального формування СТА, за кількістю виконань в світі, значно 
поступається лапоро-асистованій методиці. Головними чинниками цього $є$ практична підготовка хірурга до формування ручного лапароскопічного шовного анастомозу та використання додаткових зшиваючих апаратів, що значно підвищує вартість операції [8].

Мета дослідження. Обговорення варіантів формування СТА за методиками, які максимально спрощені, надійні, безпечні для пацієнта та економічно прийнятні.

Матеріали та методи. Наш досвід виконання лапароскопічних тотальних гастроектомій (ЛТГ) 3 приводу раку шлунку включає в себе як формування інтракорпорального степлерного СТА, так і лапароасистовані гастроектомії (ЛАГ) 3 використанням циркулярних степлерних апаратів різних конструкцій. Загалом, протягом 2017-2019 років у хірургічному відділенні ККЛ № 3 на залізничному транспорті, яке $\epsilon$ базою кафедри онкології
НМУ ім. О.О. Богомольця, виконано 67 гастроектомій. У дослідженні загалом аналізується 41 випадок, коли виконана лапароскопічна тотальна гастроектомія, з них повністю лапароскопічна методика 3 формуванням інтракорпорального анастомозу виконана у 7 пацієнтів, в 34 випадках виконувалась лапароасистована тотальна гастроектомія 3 формуванням циркулярного степлерного анастомозу. Чоловіків було 29, жінок 12 . Середній вік пацієнтів складав 57 \pm 9 років, середній індекс маси тіла (IMT) 25,0 $\pm 2,9.3$ метою прогнозування операційного ризику фізичний стан пацієнтів оцінювали за шкалою, розробленою Американським Товариством Анестезіологів (ASA). Стан 29 пацієнтів визначено як ASA II та 12 було оцінено як ASA III. Аналіз характеристики пухлини дозволив визначити стадію онкологічного захворювання як II у 17 пацієнтів, III - у 24 (табл.1).

Клінічна характеристика хворих

\begin{tabular}{|l|l|l|l|}
\hline Показник & \multicolumn{1}{|c|}{$\begin{array}{c}\text { Загальна кількість } \\
(\mathrm{n}=41)\end{array}$} & ЛТГ $(\mathrm{n}=7)$ & ЛАГ $(\mathrm{n}=34)$ \\
\hline Стать (ч/ж) & $29 / 12$ & $4 / 3$ & $21 / 13$ \\
\hline Вік (роки) & $57 \pm 9$ & $52 \pm 7$ & $57 \pm 11$ \\
\hline Індекс маси тіла (кг/M $\left.{ }^{2}\right)$ & $25,0 \pm 2,9$ & $23,0 \pm 2,3$ & $25,0 \pm 3,9$ \\
\hline За шкалою АSА (II/III) & $29 / 12$ & $5 / 2$ & $24 / 10$ \\
\hline Стадія онкологічного процесу (II/III) & $17 / 24$ & $6 / 1$ & $8 / 26$ \\
\hline
\end{tabular}

В усіх випадках лапароскопічного втручання положення пацієнта на операційному столі, встановлення основних та допоміжних троакарів, етапи мобілізації шлунку та абдомінальної частини стравоходу, лімфодисекція, виконувались за стандартною методикою.

Формування інтракорпорального СТА при ЛТГ починали з виділення петлі тонкої кишки, яку вкладали попереду ободової кишки до задньої стінки стравоходу. На задній стінці стравоходу та протибрижовій стінці відвідної петлі тонкої кишки формували технологічні отвори для лінійного зшивального апарату. Після формування механічного анастомозу бік-в-бік шлунок та стравохід пересікали лінійним степлером. Технологічні отвори в тонкій кишці та стравоході зашивали обвивним швом. Між привідною та відвідною петлями тонкої кишки, нижче зв'язки Трейца, формували анастомоз за Брауном.

При застосуванні методики ЛАГ в ділянці майбутнього анастомозу формуємо циркулярний шов, на один сантиметр нижче розсікаємо стінку стравоходу на дві третини діаметра та заводимо шляпку зшивального апарату. Після затягування шва шлунок відсікається. В подальшому виконується мінілапаротомія та формується ізольована петля тонкої кишки за Ру. Введення зшивального апарату можливо двома шляхами: 1. через місце майбутнього анастомозу за Брауном. За такою методикою були сформовані СТА у 23 пацієнтів. При такому шляху введення зшивального апарату кукса відвідної петлі тонкої кишки зашивається відразу після пересічення тонкої кишки. 2. Через куксу тонкої кишки з подальшим іiі зашиванням після формування анастомозу. Такий підхід використано у 11 випадках. В усіх випадках за зону анастомозу заводили назоінтестинальний зонд для введення рідини 3 метою стимуляції роботи кишківника.

Результати дослідження. Результати інтраопераційного перебігу та післяопераційного періоду наведені в таблиці 2.

Інтраопераційний перебіг та післяопераційні дані у паціснтів з СТА

Таблиця 2

\begin{tabular}{|c|c|c|c|c|c|c|}
\hline \multirow[t]{3}{*}{ Показник } & \multirow{2}{*}{$\begin{array}{l}\text { ЛТГ } \\
(\mathrm{n}=7)\end{array}$} & \multicolumn{2}{|c|}{ ЛАГ загалом (n-34) } & \multirow{2}{*}{\multicolumn{3}{|c|}{$\begin{array}{c}\text { Порівняння груп } \\
\text { U; p }\end{array}$}} \\
\hline & & 1 тип $(n=23)$ & 2 тип $(n=11)$ & & & \\
\hline & Me; IQR & $\mathrm{Me} ; \mathrm{IQR}$ & Me; IQR & $\begin{array}{l}\text { ЛТГ- } \\
\text { ЛАГ1 }\end{array}$ & $\begin{array}{l}\text { ЛТГ- } \\
\text { ЛАГ2 }\end{array}$ & ЛАГ1-ЛАГ2 \\
\hline $\begin{array}{l}\text { Час формування } \\
\text { анастомозу (хв.) }\end{array}$ & 48,$52 ; 31,2-54,3$ & 48,$13 ; 42-52$ & 45,$36 ; 38-52$ & $77 ; 0,86$ & $37 ; 0,89$ & $93 ; 0,21$ \\
\hline Доба відходження газів & 3,$82 ; 3,5-4,2$ & 3,$72 ; 3,3-4,1$ & 3,$7 ; 3,3-4,3$ & $64 ; 0,41$ & 32,$5 ; 0,58$ & 120,$5 ; 0,82$ \\
\hline $\begin{array}{c}\text { Початок харчування } \\
\text { (доба) }\end{array}$ & 6,$14 ; 5,8-6,8$ & 6,$01 ; 5,6-6,4$ & 5,$94 ; 5,6-6,2$ & 72,$5 ; 0,69$ & $31 ; 0,49$ & 114,$5 ; 0,65$ \\
\hline $\begin{array}{c}\text { Виписка із стаціонару } \\
\text { (доба) }\end{array}$ & 10,$64 ; 8,5-10$ & 9,$56 ; 8-10$ & 9,$36 ; 7-11$ & 76,$5 ; 0,84$ & $36 ; 0,81$ & $115 ; 0,66$ \\
\hline
\end{tabular}


Статистичну обробку результатів проводили за допомогою програми Microsoft Excel 2013 та пакету програм SPSS 21 із використанням непараметричного U-критерію Манна-Уітні для непов'язаних вибірок, визначали медіани та інтерквартильний розмах. Результат вважався статистично значимим, якщо $\mathrm{p}<0,05$. У результаті проведеного дослідження серед досліджених груп не встановлено статистично значимих відмінностей серед досліджених показників.

Усі операції, включені в дослідження, завершено лапароскопічно. Методика ЛТГ з інтракорпоральним степлерним анастомозом виконана у 7 пацієнтів. У цій групі середній час формування анастомозу складав 51,2 $\pm 18,2$ хвилин. Початок відходження газів відмічався на $3.8 \pm 1.1$ добу, харчування починали з доби 6.1 \pm 1.1 . Виписка відбувалась на $10.5 \pm 2.5$ добу. За методикою ЛАГ було прооперовано 34 хво- рих, 3 них 23 за першим типом формування анастомозу та 11 за другим типом. Середній час формування анастомозу складав $48,3 \pm 9,0$ та $45,1 \pm 7,0$ хвилин відповідно. Гази починали відходити на $3.9 \pm 1.0$ та $3,5 \pm 1.1$ добу. Виписка хворого 3 стаціонару відбувалась на $9.4 \pm 2.9$ добу при першому варіанті та $9.3 \pm 1.7$ при другому. Післяопераційні ускладнення представлені в таблиці 3. Випадків внутрішньолікарняної та тридцятиденної летальності не було. Ускладнення виникли у 3 пацієнтів в групі ЛТГ. Зокрема, у 1 пацієнта виникла неспроможність анастомозу 3 формуванням внутрішньочеревного абсцесу, у 1 кровотеча в просвіт анастомозу. У пацієнтів групи ЛАГ було зафіксовано 7 ускладнень, 3 них 3 неспроможності анастомозу, 1 внутрішньо черевний абсцес, 2 випадки кровотечі в просвіт анастомозу, 1 стриктура анастомозу.

Таблиця 3

Післяопераційні ускладнення

\begin{tabular}{|c|c|c|c|c|}
\hline \multirow[t]{2}{*}{ Показник } & \multirow{2}{*}{$\begin{array}{c}\text { ЛТГ } \\
(\mathrm{n}=7)\end{array}$} & \multicolumn{2}{|c|}{ ЛАГ(n=34) } & \multirow{2}{*}{$\begin{array}{c}\text { Загалом } \\
(\mathrm{n}=10)\end{array}$} \\
\hline & & 1 тип $(\mathrm{n}=23)$ & 2 тип $(\mathrm{n}=11)$ & \\
\hline Неспроможність анастомозу & 1 & 2 & 1 & 4 \\
\hline Кровотеча в просвіт анастомозу & 1 & 1 & 1 & 3 \\
\hline Стриктура анастомозу & & 1 & & 1 \\
\hline Внутрішньочеревний абсцес & 1 & 1 & & 2 \\
\hline
\end{tabular}

Обговорення результатів. Аналізуючи переваги та недоліки використаних підходів в формуванні СТА, слід зазначити, що як інтра-, так і екстракорпоральний підхід, мають свої переваги та недоліки. Так, методика ЛТГ відповідає всім критеріями мініінвазивних утручань у сенсі щадного ставлення до черевної стінки, зменшення больового синдрому в післяопераційному періоді [2]. Формування анастомозу в черевній порожнині відбувається без натягу, менше травмаоточуючих органів, що сприяє скорішому відновленню роботи кишечника та в повній мірі відповідає концепції "no touch tumor", що вочевидь $є$ перевагами цього методу. Наведена нами методика інтракорпорального формування СТА, на нашу думку, є найбільш простою серед існуючих, але і вона потребує від хірурга значних навичок володіння лапароскопічним ручним швом. Необхідність шовного закриття технологічних отворів в стравоході та тонкій кишці в незручному місці може викликати певні труднощі з подальшим виникненням ускладнень 3 боку анастомозу у вигляді неспроможності швів, кровотечі в просвіт анастомозу, формування внутрішньочеревного абсцесу [5]. Для профілактики таких ускладнень ми використовуємо резорбційну монофіламентну нитку для безвузлового закриття ран V-Loc 90 TM; Covidien. На нашу думку, головними обмежуючими факторами при формуванні таких анастомозів $\epsilon$ недостатня довжина абдомінальної частини стравоходу та високе розташування пухлини в кардіальному відділі шлунку. Значним стримуючим фактором широкого використання ЛТГ є економічна складова забезпечення такої методики формування CТА, яка потребує, без урахування співустя за Брауном, трьох касет для лінійного степлера та одну нитку для безвузлового шва, що з урахуванням загальної кількості розхідних матеріалів значно підвищує вартість операції [6].

В нашому досліджені найбільш вживаною виявилась методика ЛАГ, в якій формування анастомозу відбувається через мінілапаротомічний розріз в епігастральній ділянці. Головним обмеженням при цій методиці є товста черевна стінка у хворих 3 великим IMT, що значно ускладнює формування СТА в вузькому та обмеженому просторі. Перевагою відкритого варіанту формування анастомозу є економічна складова. При першому типі з'єднання тонкої кишки 3 стравоходом потрібен один циркулярний зшивальний апарат, дистальна кукса тонкої кишки звичайно обробляється вузловими швами. Важливим моментом в цій методиці є адекватний вибір діаметра зшивального апарату відповідно до діаметра відвідної петлі тонкої кишки [8], звичайно 3 діаметром голівки 21 мм. Обмеженням для такого методу може бути занадто малий діаметр тонкої кишки, що не дозволяє провести апарат до місця з'єднання з стравоходом. У такому випадку використовується другий метод 3'єднання через проксимальну куксу тонкої кишки, який не потребує значного проведення апарату через просвіт кишки [4]. При такому варіанті використовується додатковий лінійний степлер для обробки проксимальної кукси тонкої кишки після формування анастомозу. Таким чином, формування СТА при відкритому варіанті, особливо перший тип, більш прийнятні з економічної точки зору. Слід зазначити про досвід використання пристрою через стравохідне введення циркулярної голівки в складеному стані (EEA ORVIL), але ці спостереження обмежені двома випадками, що не дає змоги оцінити переваги та недоліки цього методу. Обмежена кількість спостережень зумовлена високою вартістю такого пристрою. 
Висновки. Результати нашого дослідження вказують на наявність широкого спектра вибору варіантів формування стровохідно-тонкокишкового анастомозу після тотальної гастроектомії. Однак вибір методу залежить як від досвіду хірурга у випадку 3 шовним варіантом анастомозу, так і від анатомічних особливостей пацієнта. Зокрема коротка абдомінальна частина стравоходу та високе розташування пухлини шлунку роблять метод інтракорпорального механічного формування СТА технічно складним або недоцільним. Використання варіанта формування анастомозу при лапароасистованих операціях може ускладнитись при високому IMT пацієнта або малому діаметрі відвідної петлі тонкої кишки. Важливе значення в умовах сьогодення має вартість операції, яка залежить від кількості та виду використаних зшивальних апаратів, що значним чином впливає на остаточну ціну оперативного втручання. За нашими даними, ЛАГ з першим типом формування СТА потребує найменших фінансових витрат. Підводячи підсумок, зазначимо, що вибір методу формування СТА залежить від врахування багатьох складових, а відсутність обгрунтованих досліджень 3 цього питання залишає широке поле для пошуку.

\section{References:}

1. Siegel RL, Miller KD, Jemal A. Cancer statistics, 2019. CA Cancer J Clin. 2019; Jan, 69(1):7-34. Available from: https://doi.org/10.3322/caac.21551

2. Jiang Yu, Changming Huang, Yihong Sun, et al. Chinese Laparoscopic Gastrointestinal Surgery Study (CLASS) Group. Effect of Laparoscopic vs Open Distal Gastrectomy on 3-Year Disease-Free Survival in Patients With Locally Advanced Gastric Cancer: The CLASS-01 Randomized Clinical Trial. JAMA. 2019; May, 28; 321(20):1983-1992. Available from: doi:10.1001/jama.2019.5359

3. Beyer K, Baukloh A, Kamphues C, Seeliger H, Heidecke C, Kreis M, Patrzyk M. Laparoscopic Versus Open Gastrectomy for Locally Advanced Gastric Cancer: A Systematic Review and Meta-Analysis of Randomized Controlled Studies. World Jornal Surgical Oncology. 2019; Apr, 15; 17(1):68. Available from: doi: 10.1186/s12957-019-1600-1

4. Kitano S, Iso Y, Moriyama M, Sugimachi K. Laparoscopy-assisted Billroth I gastrectomy. Surg Laparosc Endosc. 1994; 4:146.

5. Best L MJ, Mughal M, Gurusamy K. Laparoscopic Versus Open Gastrectomy for Gastric Cancer. Cochrane Database Syst Rev. 2016; Mar, 31; 3(3):CD011389. Available from: doi:10.1002/1465 1858.CD011389.pub2

6. Wang S, Ling, E Zhao, H Cao. The Surgical Treatment of Gastric Cancer in the Era of Minimally Invasive Surgery. Minerva Chir. 2017; Aug, 72(4):334-346. Available from: doi:10.23736/S0026-4733.17.073473

7. Zhao EH, Ling TL, Cao H. Current status of surgical treatment of gastric cancer in the era of minimally invasive surgery in China: Opportunity and challenge. Int J Surg. 2016; Apr, 28:45-50. Available from: doi:10.1016/j.ijsu.2016.02.027.
8. Costantino CL, Mullen JT. Minimally Invasive Gastric Cancer Surgery. Surg Oncol Clin N Am. 2019; Apr, 28(2):201-213. Available from: doi:10.1016/j.soc. 2018.11.007.

УДК 616.33-006.6

ФОРМИРОВАНИЕ

ЭЗОФАГО-ЕЮНОАНАСТОМОЗА ПОСЛЕ ЛАПАРОСКОПИЧЕСКОЙ ТОТАЛЬНОЙ И ЛАПАРО-АСИСТИРОВАННОЙ ГАСТРЕКТОМИИ У БОЛЬНЫХ С РАКОМ ЖЕЛУДКА

И.А. Сухин, Р.И. Верещако, А.А. Пискорский, А.Н. Белиловец, Р.С. Гилевич

Национальный медицинский университет имени

А.А. Богомольиа, кафедра онкологии,

2. Киев, Украина,

ORCID ID: 0000-0002-0177-9306,

ORCID ID: 0000-0002-5706-6823,

ORCID ID: 0000-0002-2202-4201,

ORCID ID: 0000-0002-4689-5490,

ORCID ID: 0000-0002-2046-6006,

e-mail:kklzt3@gmail.com

Резюме. В настоящее время рак желудка стоит на втором месте по причинам смерти от онкологических заболеваний. Существует два варианта хирургического лечения потенциально излечимых пациентов с неметастатическим раком желудка, это лапароскопическая и открытая гастроэктомия. Соответственно есть необходимость обсуждения вариантов формирования эзофаго-еюноанастомозов по методикам, максимально упрощенным, надежным, безопасным для пациента и экономически приемлемым. В статье исследованы методы формирования различных типов пищеводно-кишечных анастомозов, в частности при лапароскопической тотальный и лапароасистованной гастроэктомии. В работе анализируются результаты лечения 41 пациента. Мужчин было 29, женщин 12. Средний возраст пациентов составлял 57 \pm 9 лет, средний индекс массы тела (ИМТ) 25,0 $\pm 2,9$. С целью прогнозирования операционного риска физическое состояние пациентов оценивали по шкале, разработанной Американским Обществом Анестезиологов (ASA). Состояние 29 пациентов определено как ASA II и 12 было оценено как ASA III. Анализ характеристики опухоли позволил определить стадию онкологического заболевания как II у 17 пациентов и III у 24 пациентов. Выбор метода формирования анастомоза зависит от опыта хирурга, анатомических особенностей пациента и экономической составляющей по количеству расходных материалов.

7 пациентам была выполнена лапароскопическая тотальная гастроэктомия с формированием интракорпорального анастомоза. Остальным 34 пациентоам выполнялась лапаро-асистованная тотальная гастроэктомия с формированием циркулярного степлерного анастомоза двумя способами:

1) введением сшивающего аппарата через место будущего анастомоза по Брауну, кукса отводной петли тонкой кишки зашивалась сразу после 
пересечения тонкой кишки, по такой методике были сформированы ЭЕА у 23 пациентов;

2) введение сшивающего аппарата через куксу тонкой кишки с дальнейшим ее зашиванием после формирования анастомоза, такой подход использовано в 11 случаях.

Ключевые слова: гастрэктомия, эзофагоеюноанастомоз, рак желудка.

\section{UDC 616.33-006.6 \\ FORMATION OF EZOFAGOEYUNO- ANASTOMOSIS AFTER LAPAROSCOPIC TOTAL GASTRECTOMY AND LAPAROSCOPY- ASSISTED GASTROECTOMY IN PATIENTS WITH GASTRIC CANCER}

\author{
I.A. Sukhin, R.I. Vereschako, O.O. Piskorskiy, \\ O.M. Bilylovets, R.S. Gulevich
}

Bogomolets National Medical University, Department of Oncology, Kyiv, Ukraine,

ORCID ID: 0000-0002-0177-9306,

ORCID ID: 0000-0002-5706-6823,

ORCID ID: 0000-0002-2202-4201,

ORCID ID: 0000-0002-4689-5490,

ORCID ID: 0000-0002-2046-6006,

e-mail:kklzt3@gmail.com

\begin{abstract}
At present, stomach cancer is the second most common cause of cancer death. There are two options for surgical treatment of potentially curable patients with non-metastatic gastric cancer: laparoscopic and open gastrectomy. Accordingly, there is a need to discuss options for the formation of esophago-jejuno anastomosis techniques that would be maximum simple, reliable, safe and cost-effective for the patient. The article investigates methods of formation of different types of esophageal and intestinal anastomoses, in particular, in laparoscopic total gastrectomy and laparoscopy-assisted gastroectomy. The results of 41 patients were analyzed in this work; 7 of them underwent laparoscopic total gastrectomy with the formation of intracorporeal anastomosis, and 34 patients underwent laparoscopy-assisted total gastrectomy with formation of circumferential stapled anastomosis. There were 29 men and 12 women.
\end{abstract}

The mean age of patients was $57 \pm 9$ years; the Body Mass Index (BMI) was $25.0 \pm 2.9$. In order to predict a surgical risk, physical status of patients was estimated under the scale developed by the American Society of Anesthesiologists (ASA). Condition of 29 patients was estimated as ASA II, and of 12 others - as ASA III. Analysis of tumor characteristics allowed to determine the stage of cancer as II in 17 patients and as III in 24 patients. A choice of method of anastomosis formation depends on the surgeon's experience, anatomical features of the patient, and economic component of consumables. All surgeries included into the research were completed laparoscopically. LTG with intracorporeal staple anastomosis was performed in 7 patients. In this group the average time of anastomosis formation was 51.2 \pm 18.2 minutes. Flatulence was observed on $3.8 \pm 1.1$ day, feeding began on $6.1 \pm 1.1$ day. A discharge took place on $10.5 \pm 2.5$ day. 34 patients underwent surgeries under the LAG technique, 23 of them had anastomosis formation of the first type and 11 - of the second one. The mean time of anastomosis formation was $48.3 \pm 9.0$ and $45.1 \pm 7.0$ minutes respectively. First flatus was on $3.9 \pm 1.0$ and 3.5 \pm 1.1 day. The patient was discharged from hospital on $9.4 \pm 2.9$ day if there was formation of the first type, and on $9.3 \pm 1.7$ day if there was the second one. Postoperative complications are given in Table 3. There were no cases of in-hospital and thirty-day mortality. Complications were found in 3 patients in the LTG group. The patient was unable to form anastomosis but found an intra-abdominal abscess and there was bleeding into the anastomotic lumen. The patients in the LAG group suffered 7 complications, including 3 failures of anastomosis, 1 intra-abdominal abscess, 2 cases of bleeding into the anastomotic lumen, 1 anastomotic stricture. While analyzing advantages and disadvantages of the approaches used in the formation of EEA, it should be noted that both intra- and extracorporeal approaches have their advantages and disadvantages. Thus, LTG meets all the criteria of mini-invasive interventions in the sense of gentle abdominal wall treatment and reduction of pain in postoperative period. The formation of the anastomosis in the abdominal cavity occurs without tension, the injury to the surrounding organs is less, which promotes faster recovery of intestinal function and fully corresponds to the "no touch tumor" principle, which are obviously the advantages of this technique. In our opinion, the presented method of intracorporeal formation of EEA is the simplest among existing ones, but it also requires significant skills from a surgeon in mastering handmade sutures. The main advantage of the open anastomosis is the economic component.

Keywords: gastrectomy, esophago-jejuno anastomosis, stomach cancer. 